\title{
Assessment of Continuous Oil and Gas Resources in the Niobrara Interval of the Cody Shale, Wind River Basin Province, Wyoming, 2018
}

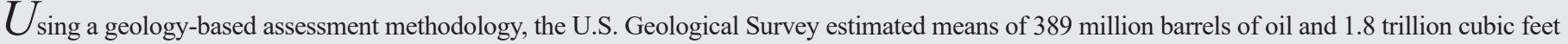 \\ of gas in the Niobrara interval of the Cody Shale in the Wind River Basin Province, Wyoming.
}

\section{Introduction}

The U.S. Geological Survey (USGS) quantitatively assessed the potential for undiscovered, technically recoverable continuous (unconventional) oil and gas resources in the Niobrara interval of the Cody Shale in the Wind River Basin Province, Wyoming (fig. 1). In the Wind River Basin, the Niobrara interval is represented by gray-to-black shale, calcareous shale, marl, and bentonite, with minor amounts of siltstone and sandstone in the lower part of the Upper Cretaceous Cody Shale (Finn, 2017). The strata were deposited in an epicontinental seaway that occupied an elongate north-south foreland basin that was bordered on the west by the tectonically active Cordilleran orogenic belt and on the east by the low-lying, stable North American craton (DeCelles, 2004). At its maximum extent, the seaway extended for more than 3,000 miles from the Arctic Ocean to the Gulf of Mexico (Kauffman, 1977). During the Laramide orogeny (Late Cretaceous through early Eocene), the central part of the foreland basin was fragmented into numerous smaller basins, including the Wind River Basin, that were flanked by rising basement-cored uplifts. These basins subsided rapidly and were depocenters for the accumulation of thick lacustrine and continental sediments from latest Cretaceous through middle Miocene time (Love, 1988).

\section{Total Petroleum System and Assessment Units}

Johnson and others (2007) defined the Cretaceous-Lower Tertiary Composite Total Petroleum System (TPS) in the Wind River Basin Province to include strata from the base of the Lower Cretaceous to the base of the Paleocene Waltman Shale and to include lower Eocene strata where the Waltman is absent. The Niobrara interval of the lower part of the Cody Shale is an element of the Cretaceous-Lower Tertiary Composite TPS and includes both source and reservoir rocks. Source rocks occur in both the Niobrara interval and the underlying Sage Breaks interval and have total organic carbon contents of as much as 6 weight percent. The organic matter in these source rocks consists of Type II and mixed Type II/III kerogen with hydrogen index values of as much as 530 milligrams of hydrocarbon per gram of organic carbon. Potential reservoirs have carbonate contents of as much as 60 percent. The more calcareous zones are often characterized by varying amounts of coccolith-rich fecal pellets that appear as distinctive "white specks" like those described by Hattin (1975). The Niobrara interval is more organic rich, oil prone, and calcareous in the central and eastern parts of the basin. Thermal maturity mapping, based on vitrinite reflectance $\left(\mathrm{R}_{\mathrm{o}}\right)$, shows that the Niobrara interval is thermally mature for oil generation ( $0.6-1.35$ percent $\left.R_{o}\right)$ along the western and southern margins of the basin and mature for gas generation (greater than 1.35 percent $\mathrm{R}_{\mathrm{o}}$ ) in the deeper central and northern parts of the basin (Finn and Pawlewicz, 2013). The Late Cretaceous through early Eocene Laramide orogeny and post-Laramide burial are considered to have thermally matured these organic-rich shales (Roberts and others, 2007).

The geologic model for the Niobrara interval continuous accumulations is that oil and gas were generated from oil-prone source rocks primarily during Laramide and post-Laramide burial. Oil and gas were partially retained within the Niobrara interval following generation and migration into adjacent reservoirs. Two assessment units (AUs) were defined: (1) the Wind River Niobrara Shale Oil AU encompasses the area within the oil-generation window ( $0.60-1.35$ percent $\left.\mathrm{R}_{\mathrm{o}}\right)$ and (2) the Wind River Niobrara Shale Gas AU includes the area where oil has been cracked to gas (greater than 1.35 percent $\mathrm{R}_{\mathrm{o}}$ ).

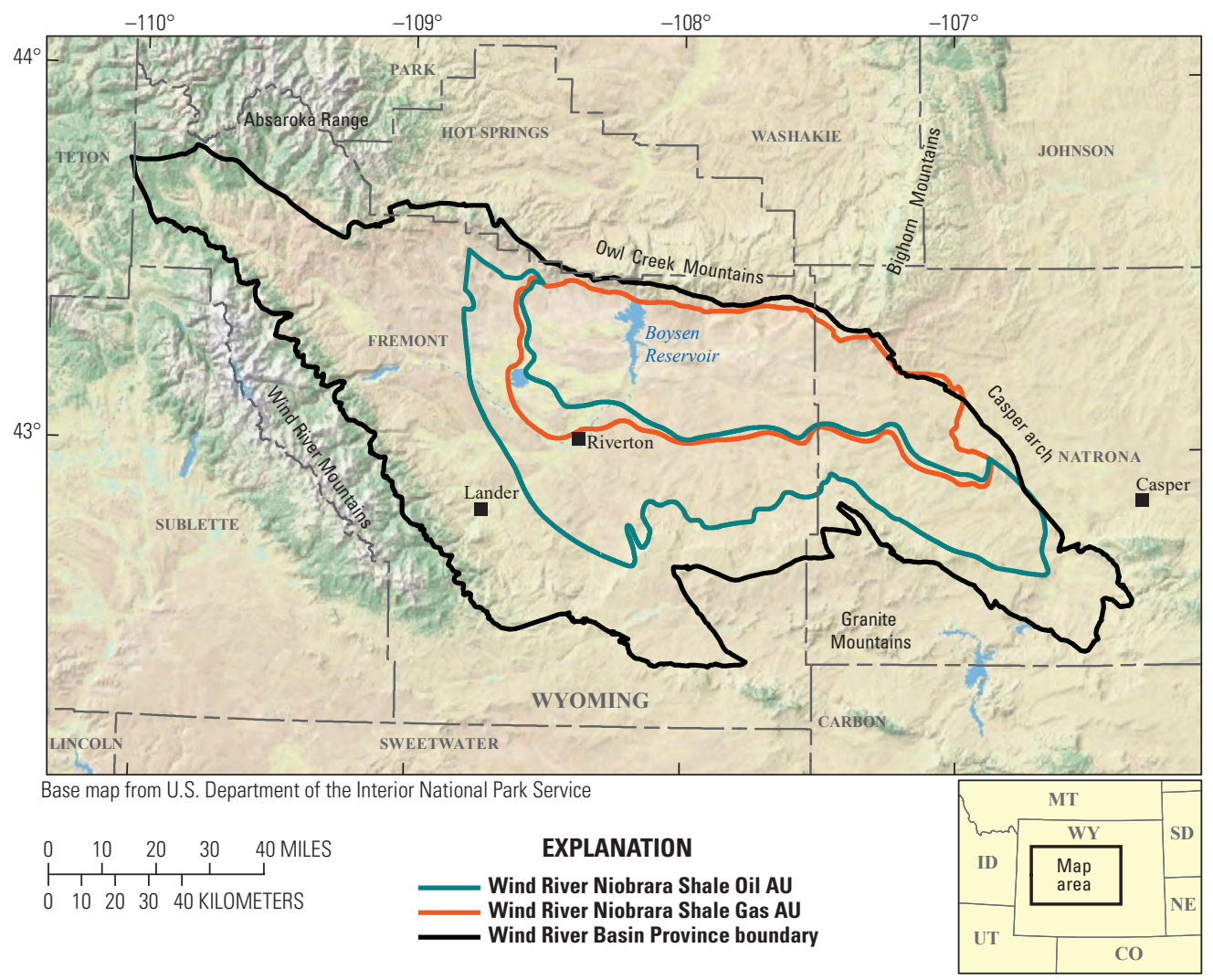

Figure 1. Map showing the continuous oil and gas assessment units (AUs) in the Niobrara interval of the Cody Shale in the Wind River Basin Province, Wyoming. Province boundary is from Johnson and others (2007). 
Table 1. Key input data for two continuous assessment units (AUs) in the Niobrara interval of the Cody Shale in the Wind River Basin Province, Wyoming.

[AU, assessment unit; \%, percent; EUR, estimated ultimate recovery per well; MMBO, million barrels of oil; BCFG, billion cubic feet of gas. Well drainage area, success ratio, and EUR are defined partly using U.S. shale-oil analogs. The average EUR input is the minimum, median, maximum, and calculated mean. Shading indicates not applicable]

\begin{tabular}{|c|c|c|c|c|c|c|c|c|}
\hline \multirow{2}{*}{$\begin{array}{c}\text { Assessment input data- } \\
\text { Continuous AUs }\end{array}$} & \multicolumn{4}{|c|}{ Wind River Niobrara Shale Oil AU } & \multicolumn{4}{|c|}{ Wind River Niobrara Shale Gas AU } \\
\hline & Minimum & Mode & Maximum & $\begin{array}{c}\text { Calculated } \\
\text { mean }\end{array}$ & Minimum & Mode & Maximum & $\begin{array}{c}\text { Calculated } \\
\text { mean }\end{array}$ \\
\hline Potential production area of AU (acres) & 1,000 & 713,000 & $1,264,000$ & 659,333 & 1,000 & 719,000 & $1,198,000$ & 639,333 \\
\hline Average drainage area of wells (acres) & 40 & 120 & 200 & 120 & 80 & 120 & 180 & 126.7 \\
\hline Success ratio $(\%)$ & 10 & 50 & 90 & 50 & 10 & 50 & 90 & 50 \\
\hline Average EUR (MMBO, oil; BCFG, gas) & 0.06 & 0.13 & 0.2 & 0.132 & 0.1 & 0.5 & 2.0 & 0.581 \\
\hline AU probability & 1.0 & & & & 1.0 & & & \\
\hline
\end{tabular}

Table 2. Results for two continuous assessment units (AUs) in the Niobrara interval of the Cody Shale in the Wind River Basin Province, Wyoming. [MMBO, million barrels of oil; BCFG, billion cubic feet of gas; NGL, natural gas liquids; MMBNGL, million barrels of natural gas liquids. Results shown are fully risked estimates. F95 represents a 95-percent chance of at least the amount tabulated; other fractiles are defined similarly. Fractiles are additive under the assumption of perfect positive correlation. Shading indicates not applicable]

\begin{tabular}{|c|c|c|c|c|c|c|c|c|c|c|c|c|c|c|}
\hline \multirow{3}{*}{$\begin{array}{l}\text { Total petroleum system } \\
\text { and assessment units (AUs) }\end{array}$} & \multirow{3}{*}{$\begin{array}{c}\text { AU } \\
\text { probability }\end{array}$} & \multirow{3}{*}{$\begin{array}{c}\text { Accumulation } \\
\text { type }\end{array}$} & \multicolumn{12}{|c|}{ Total undiscovered resources } \\
\hline & & & \multicolumn{4}{|c|}{ Oil (MМBO) } & \multicolumn{4}{|c|}{ Gas (BCFG) } & \multicolumn{4}{|c|}{ NGL (MMBNGL) } \\
\hline & & & F95 & F50 & F5 & Mean & F95 & F50 & $\mathbf{F 5}$ & Mean & F95 & F50 & F5 & Mean \\
\hline \multicolumn{15}{|c|}{ Cretaceous-Lower Tertiary Composite Total Petroleum System } \\
\hline Wind River Niobrara Shale Oil AU & 1.0 & Oil & 90 & 346 & 834 & 389 & 90 & 336 & 870 & 389 & 5 & 20 & 55 & 23 \\
\hline Wind River Niobrara Shale Gas AU & 1.0 & Gas & & & & & 287 & 1,169 & 3,535 & 1,442 & 1 & 5 & 24 & 8 \\
\hline $\begin{array}{l}\text { Total undiscovered continuous } \\
\text { resources }\end{array}$ & & & 90 & 346 & 834 & 389 & 377 & 1,505 & 4,405 & 1,831 & 6 & 25 & 79 & 31 \\
\hline
\end{tabular}

Assessment input data are summarized in table 1. Input data for estimated ultimate recoveries of wells are taken from the geologic analog in the Sand Wash Basin part of the Southwestern Wyoming Province.

\section{Undiscovered Resources Summary}

The USGS quantitatively assessed continuous oil and gas resources in the two delineated AUs (table 2) in the Niobrara interval of the Wind River Basin Province, Wyoming. For undiscovered, technically recoverable continuous oil and gas resources, the estimated mean totals are 389 million barrels of oil (MMBO) with an F95-F5 fractile range from 90 to $834 \mathrm{MMBO} ; 1,831$ billion cubic feet of gas (BCFG), or 1.8 trillion cubic feet of gas, with an F95-F5 fractile range from 377 to 4,405 BCFG; and 31 million barrels of natural gas liquids (MMBNGL) with an F95-F5 fractile range from 6 to 79 MMBNGL.

\section{Niobrara Assessment Team}

Thomas M. Finn, Christopher J. Schenk, Tracey J. Mercier, Marilyn E. Tennyson, Phuong A. Le, Michael E. Brownfield, Kristen R. Marra, Heidi M. Leathers-Miller, Ronald M. Drake II, Cheryl A. Woodall, and Scott A. Kinney

\section{For More Information}

Assessment results are also available at the USGS Energy

Resources Program website at https://energy.usgs.gov.

\section{References Cited}

DeCelles, P.G., 2004, Late Jurassic to Eocene evolution of the Cordilleran thrust belt and foreland basin system, western U.S.A.: American Journal of Science, v. 304, no. 2, p. 105-168

Finn, T.M., 2017, Stratigraphic cross sections of the Niobrara interval of the Cody Shale and associated rocks in the Wind River Basin, central Wyoming: U.S. Geological Survey Scientific Investigations Map 3370, 19 p., 1 sheet, accessed June 1, 2018, at https://doi.org/10.3133/sim3370.

Finn, T.M., and Pawlewicz, M.J., 2013, Maps showing thermal maturity of Upper Cretaceous marine shales in the Wind River Basin, Wyoming: U.S. Geological Survey Scientific Investigations Map 3266, 13 p., 1 sheet, scale 1:500,000, accessed May 1, 2018, at http://doi.org/10.3133/sim3266.

Hattin, D.E., 1975, Petrology and origin of fecal pellets in Upper Cretaceous strata of Kansas and Saskatchewan: Journal of Sedimentary Petrology, v. 45, no. 3, p. 686-696.

Johnson, R.C., Finn, T.M., Kirschbaum, M.A., Roberts, S.B., Roberts, L.N.R., Cook, T., and Taylor, D.J., 2007, The Cretaceous-Lower Tertiary Composite Total Petroleum System, Wind River Basin, Wyoming, chap. 4 of USGS Wind River Basin Province Assessment Team, Petroleum systems and geologic assessment of oil and gas in the Wind River Basin Province, Wyoming: U.S. Geological Survey Digital Data Series DDS-69-J, 96 p.

Kauffman, E.G., 1977, Geological and biological overview-Western Interior Cretaceous basin, in Kauffman, E.G., ed., Cretaceous facies, faunas, and paleoenvironments across the Western Interior Basin: Denver, Colo., Rocky Mountain Association of Geologists, The Mountain Geologist, v. 14, nos. 3-4, p. 75-99.

Love, J.D., 1988, Geology of the Wind River Basin, central Wyoming, in Basins of the Rocky Mountain region, chap. 8 of Sloss, L.L., ed., Sedimentary cover-North American craton-U.S., v. D-2 of The geology of North America: Boulder, Colo., The Geological Society of America, p. 196-200.

Roberts, L.N.R., Finn, T.M., Lewan, M.D., and Kirschbaum, M.A., 2007, Burial history, thermal maturity, and oil and gas generation history of petroleum systems in the Wind River Basin Province, central Wyoming, chap. 6 of USGS Wind River Basin Province Assessment Team, Petroleum systems and geologic assessment of oil and gas in the Wind River Basin Province, Wyoming: U.S. Geological Survey Digital Data Series DDS-69-J, 26 p. 